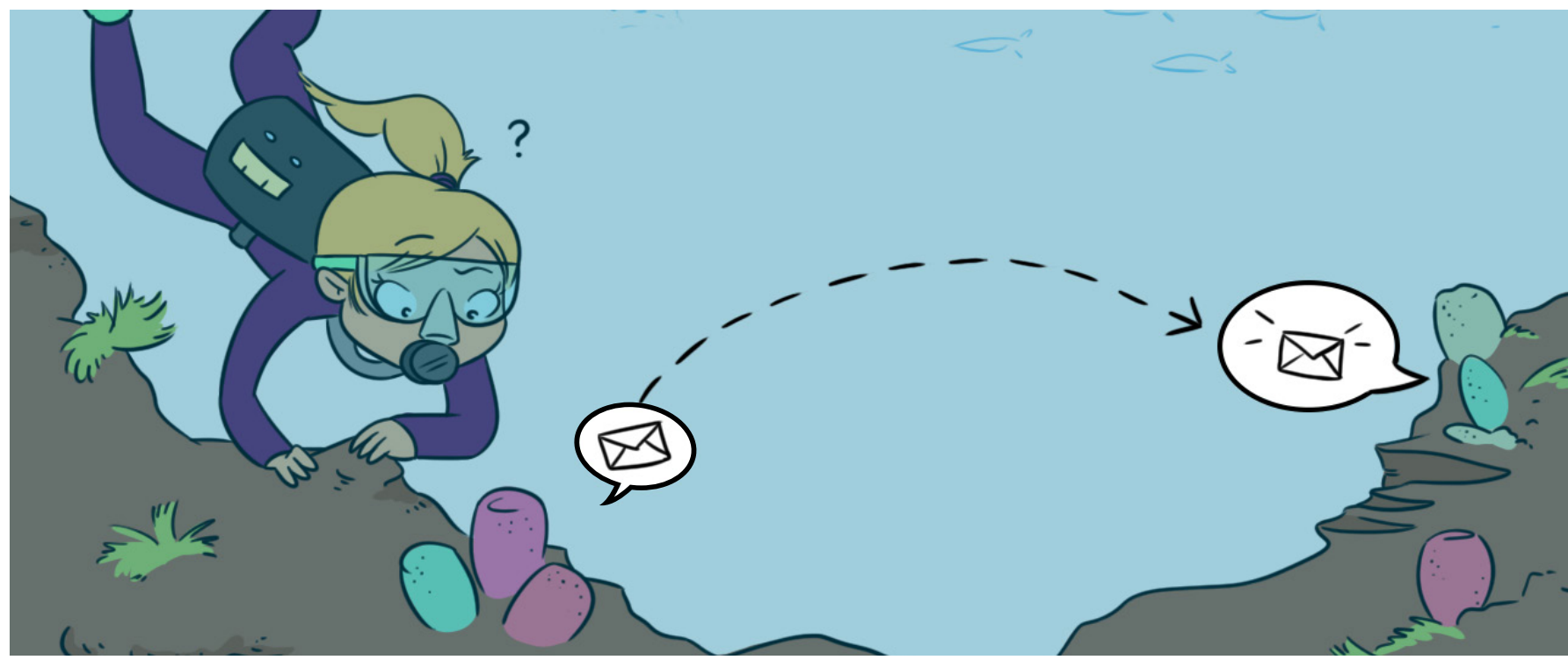

\title{
DO YOU KNOW THAT MICROBES USE SOCIAL
}

\section{NETWORKS?}

\section{Valeria Costantino* and Germana Esposito}

The Blue Chemistry Laboratory Group, Department of Pharmacy, University of Naples Federico II, Naples, Italy

REVIEWED BY:

ISTITUTO

COMPRENSIVO FOSCOLO OBERDAN AGE: 12-13
ANTIMICROBIAL COMPOUNDS

Molecules able to kill microorganisms or stop their growth.
Bacteria do have a social life. They talk to each other by releasing simple chemicals. This system is called quorum sensing. When the bacteria are growing in your body and the amount of quorum sensing chemicals reaches a certain level, you begin to feel sick. There are other types of molecules that can block this system and they are called quorum quenching agents (QQAs). We wish to design new drugs that act as QQAs. In this article, we describe how we isolated a new molecule from a marine sponge. This molecule, called plakofuranolactone, works as a QQA.

\section{DID YOU KNOW THAT SOME MEDICINES COME FROM THE SEA?}

Sponges, algae, and other marine organisms produce many kinds of molecules. Scientists can use these molecules to design new types of drugs. Our research group studies the molecules produced by sponges that live in the ocean. We hope to use these molecules to make new medicines to fight common diseases or infections caused by bacteria. We usually fight bacterial infections by taking medicines that are antimicrobial compounds also called antibiotics. Antibiotics work by killing the bacteria that infect us and make us feel sick. 


\section{WHY ARE WE SEARCHING FOR NEW DRUGS TO} FIGHT BACTERIA?

As you may know from science class, there are many bacteria that normally live in and on your body. For example, there are some bacteria living in the intestines that help to digest food and to maintain good health. When we take antibiotics to fight a bacterial infection (a bacterium that causes a disease in the body is called a pathogen), the antibiotic will kill both the good bacteria in the body and the pathogen. The death of the good bacteria causes intestinal problems in some people. In addition, some bacteria can become resistant to the antibiotics, meaning that the antibiotics can no longer kill them. As a result, there are some very dangerous infections that cannot be cured with antibiotics. Because of this, we wish to explore a different way to fight bacterial diseases.

\section{HOW DID WE LOOK FOR A NEW DRUG FROM MARINE SPONGES?}

Marine sponges are invertebrate animals able to obtain nourishment by filtering water. Several steps were followed in order to obtain a new drug from the sponges.

\section{STEPS}

\section{COLLECTION}

We collected small samples from many different marine sponges while we were diving along the Caribbean and Indonesian coasts from a scientific vessel. The sponges do not suffer when we take samples from them-they easily regrow.

\section{EXTRACTION}

The marine sponge samples were stored frozen until we got back to the lab. Then, we treated the samples with some liquid chemicals (called solvents) also that we could take out all of the substances present in the piece of the sponge. This process is called "extraction" (Figure 1). If you look at Figure 1, you will see the details of the process.

After the extraction, we collected a mixture of all the substances present in the sponge.

\section{PURIFICATION}

PURIFICATION

Separation of a mixture of compounds.
Next, we purified the individual substances in the mixture we got from the extraction into many pure compounds. This step, called purification, is done using a technique called "chromatography," in which a glass tube (the column) is filled with a solid, gel-like material. We loaded the mixture of substances we got from the extraction onto the column. Then, a number of solvents were run through the column and a number of fractions were collected. These fractions 


\section{FIGURE 1}

The purification process of plakofuranolactone.

1. Collection of sponges.

2. Extraction of the sponge samples with different solvents.

3. Purification of the mixture of extracted compounds to obtain pure compounds.

4. Identification of the structure of the pure compound. 5. The new compound is used to create a new drug. $\mathbf{6}$. The activity of the new drug is tested. 7. The new drug is complete and can be used to help people fight a bacterial infection.

\section{FIGURE 2}

The structure of the plakofuranolactone molecule.
QUORUM SENSING

Communication mechanism between bacteria.
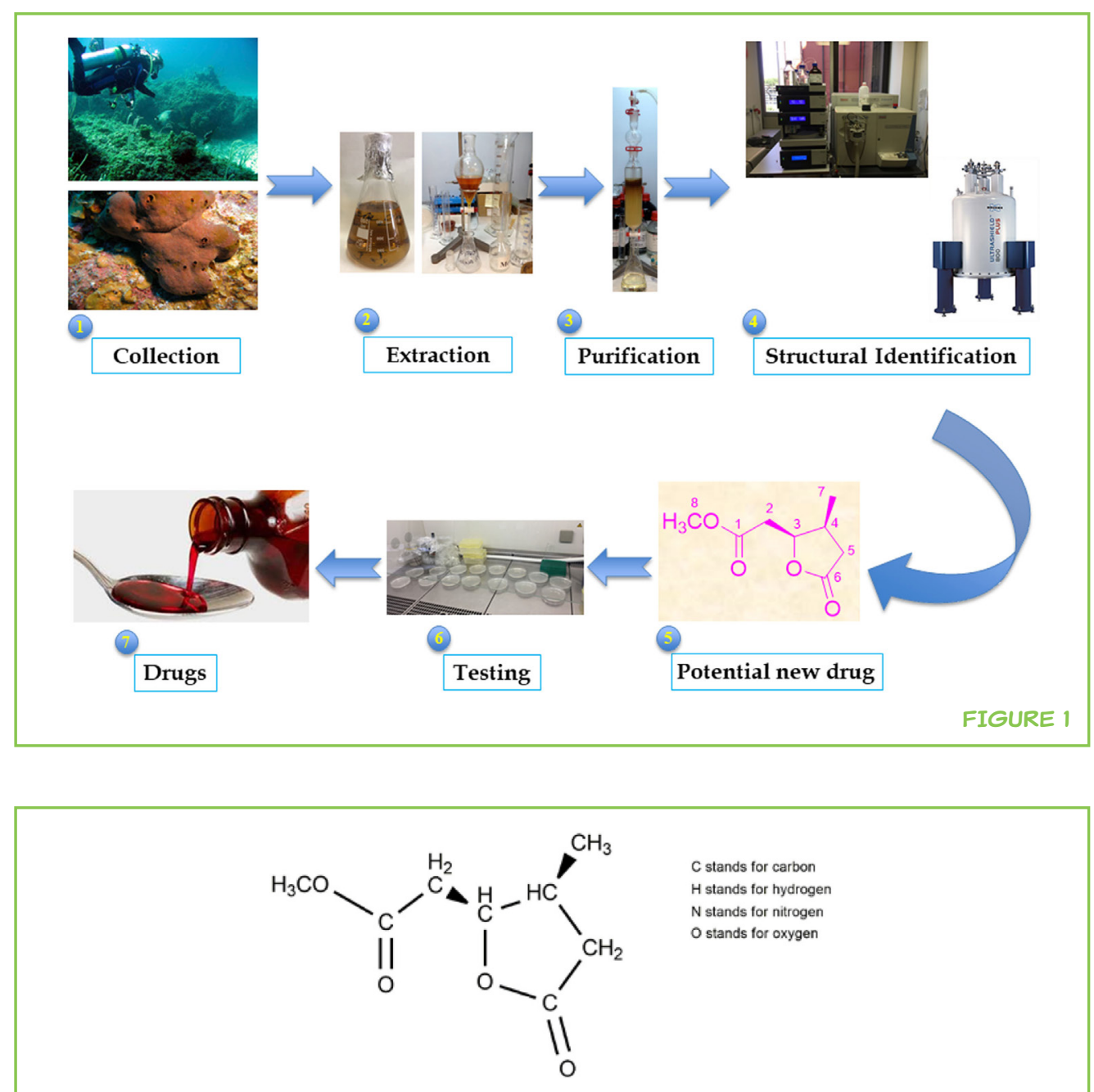

FIGURE 2

contained the pure substances that had been separated each other, and these are the pure compounds.

\section{IDENTIFICATION}

Using another scientific technique, called spectroscopic analysis, we were able figure out the chemical structure of the pure compound we got from the purification. We put all the data together, like the pieces of a puzzle, to identify the structure of the compound. We named this compound plakofuranolactone and its chemical structure is shown in Figure 2.

\section{QUORUM SENSING AND QUORUM QUENCHING}

Bacteria can communicate with each other. They do this by releasing very simple molecules that are detected by other bacteria. This process is called quorum sensing. When there are a lot of pathogenic bacteria in the body, there will be a high concentration of quorum sensing molecules. When the concentration of these molecules gets high enough, we start to feel sick. 


\section{FIGURE 3}

Communication among bacteria. The quorum sensing system allows bacteria to communicate using small molecules.

When bacteria communicate each other, they produce a message that make us start feeling sick.

\section{QUORUM}

\section{QUENCHING}

AGENTS

Molecule able to stop the communication between bacteria.

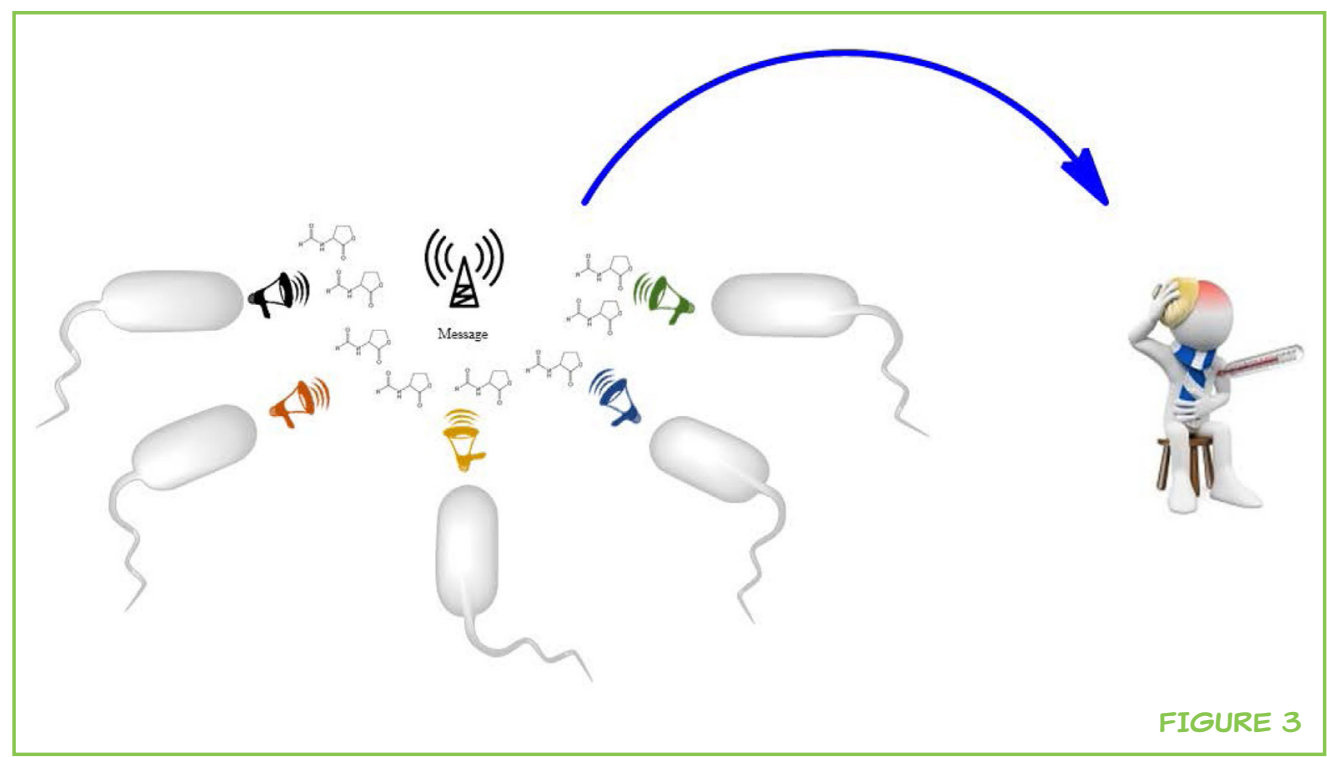

(Figure 3) some interesting substances can block the action of quorum sensing molecules, making pathogenic bacteria less dangerous, and helping us not to get so sick. These substances are called quorum quenching agents (QQAs).

Keeping in mind the idea that we need new medicines to fight some bacterial pathogens, particularly those that have become resistant to antibiotics, we decide to study the activity of plakofuranolactone, to see if it might be a QQA. Plakofuranolactone is very similar, but not identical [1], to the chemical that a very dangerous pathogenic bacterium called Pseudomonas aeruginosa uses to communicate and to create a social network of bacteria that are able to act together to attack the enemy (in this case your body). Using a laboratory test, we were able to show that plakofuranolactone blocks the quorum sensing system of $P$. aeruginosa, reducing its virulence.

\section{DID WE CREATE A NEW DRUG?}

No yet. The work we have described is only the first step of a very long process. Plakofuranolactone will now be used to design a new class of medicines that reduce bacteria virulence. The next step of this work is to understand how plakofuranolactone acts inside the bacterial cell.

\section{CONCLUSION}

Bacteria do have a social life. They can communicate with each other using small molecules as their language. We found a way to block this communication in the pathogenic bacteria $P$. aeruginosa and reduce its virulence. The work that we have done opens the way to a novel class of medicines that will reduce bacterial virulence, making them less dangerous, instead of killing them. In the 
future, this kind of medicine could prevent the deaths of many people from bacterial infections that, at the moment, cannot be cured.

\section{ORIGINAL SOURCE ARTICLE}

Costantino, V., Della Sala, G., Saurav, K., Teta, R., Bar-Shalom, R., Mangoni, A., et al. 2017. Plakofuranolactone as a quorum quenching agent from the Indonesian Sponge Plakortis cf. lita. Mar. Drugs 15:59. doi:10.3390/md15030059

\section{REFERENCE}

1. Costantino, V., Della Sala, G., Saurav, K., Teta, R., Bar-Shalom, R., Mangoni, A., et al. 2017. Plakofuranolactone as a quorum quenching agent from the Indonesian Sponge Plakortis cf. lita. Mar. Drugs 15:59. doi:10.3390/md15030059

SUBMITTED: 31 January 2018; ACCEPTED: 13 June 2018;

PUBLISHED ONLINE: 26 June 2018.

EDITED BY: Rossana De Lorenzi, Associazione Adamas Scienza, Italy

CITATION: Costantino V and Esposito G (2018) Do You Know That Microbes Use Social Networks? Front. Young Minds 6:31. doi:10.3389/frym.2018.00031

CONFLICT OF INTEREST STATEMENT: The authors declare that the research was conducted in the absence of any commercial or financial relationships that could be construed as a potential conflict of interest.

COPYRIGHT @ 2018 Costantino and Esposito. This is an open-access article distributed under the terms of the Creative Commons Attribution License (CC BY). The use, distribution or reproduction in other forums is permitted, provided the original author(s) and the copyright owner are credited and that the original publication in this journal is cited, in accordance with accepted academic practice. No use, distribution or reproduction is permitted which does not comply with these terms.

\section{REVIEWED BY}

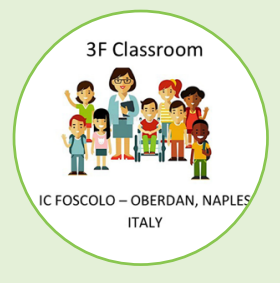

\section{ISTITUTO COMPRENSIVO FOSCOLO OBERDAN, AGE: 12-13}

The reviewers are a group of students of the $3 F$ class, ages ranging from 12 to 13 years, of a Secondary School "IC FOSCOLO-OBERDAN" in Naples, Italy. It was an exciting experience and we are passionate about the article. We think this experience is very useful for us because we have understood how difficult it is to make good communication. Our work has served writers to make their paper easier and more understandable, even to children of our age, and we believe that this is a success for everyone. The revision project was realized with the help of our scientific mentor, teacher Floriana Fabbrini. 


\section{AUTHORS}

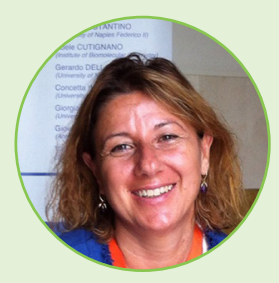

\section{VALERIA COSTANTINO}

Valeria is professor of Organic chemistry and Chemistry of Natural products at University of Naples "Federico II," Italy. She loves Nature and Chemistry at the same manner and loves diving and climbing as well as working in the lab with her collaborators. Her research focuses on exploring the unique natural products of marine sponges and cyanobacteria as lead compound for pharmacological applications in the areas of cancer, inflammation, and infectious disease. More recently, she has also applied the chemical knowledge to explore the QS system in bacteria symbiotic with sponges with the goal to create novel leads in anti-virulence drugs. *valeria.costantino@unina.it

\section{GERMANA ESPOSITO}

I am a researcher and love to study all things related to the chemistry of natural products and microorganisms. My current research deals with marine sponges and their symbiont microorganisms, in particular cyanobacteria. We are trying to find new molecules that can be used as potential drugs. I am currently trying to grow cyanobacteria in the laboratory in such a way that we can easily get a large amount certain (active) molecules out of them. You can find me in the lab of Prof. Valeria Costantino for my post-doctoral studies at the University of Naples Federico II. 